\title{
Collared Pecary (tayassu tajacu) as a new model of renal ischemic injury induced by clamping the renal artery ${ }^{1}$
}

\author{
Dayseanny de Oliveira BezerraI, Matheus Levi Tajra Feitosa ${ }^{\mathrm{II}}$, Hatawa Melo de Almeida ${ }^{\mathrm{III}}$, Francisco Assis Lima Costa ${ }^{\mathrm{IV}}$, Juliana \\ Fortes Vilarinho Braga ${ }^{\text {V }}$ Francisco de Assis Leite Souza ${ }^{\mathrm{VI}}$, Flávio Ribeiro Alves ${ }^{\mathrm{VII}}$, Gerson Tavares Pessoa ${ }^{\mathrm{VIII}}$, Maria Acelina \\ Martins de Carvalho ${ }^{\mathrm{IX}}$
}

DOI: http://dx.doi.org/10.1590/S0102-8650201400150003

IFellow PhD degree, Veterinary Morphophisiology Department, Postgraduate Program in Animal Science, Federal University of Piaui (UFPI), TeresinaPI, Brazil. Technical procedures, design of the study, manuscript preparation.

IIPhD, Fellow Post-Doctoral degree, Veterinary Morphophisiology Department, Postgraduate Program in Animal Science, UFPI, Teresina-PI, Brazil. Technical procedures, manuscript preparation.

IIIFellow PhD degree, Veterinary Morphophisiology Department, Postgraduate Program in Animal Science, UFPI, Teresina-PI, Brazil. Technical procedures. ${ }^{\mathrm{IV}} \mathrm{PhD}$, Associate Professor, Veterinary Clinical and Surgery Department, UFPI, Teresina-PI, Brazil. Histopathological examinations, manuscript writing. ${ }^{v}$ Fellow PhD degree, Veterinary Patology Department, Postgraduate Program in Animal Pathology, Federal University of Minas Gerais (UFMG), Belo Horizonte-MG, Brazil. Histopathological examinations.

${ }^{\mathrm{VI}}$ Fellow PhD degree, Veterinary Clinical and Surgery Department, Postgraduate Program in Animal Science, UFPI, Teresina-PI, Brazil. Laboratory tests. ${ }^{V I I} \mathrm{PhD}$, Associate Professor, Veterinary Morphophisiology Department, Postgraduate Program in Animal Science, UFPI, Teresina-PI, Brazil. Ultrassonography tests.

${ }^{\mathrm{VIII}}$ Fellow PhD degree, Veterinary Morphophisiology Department, Postgraduate Program in Animal Science, UFPI, Teresina-PI, Brazil. Technical procedures. ${ }^{\mathrm{Ix}} \mathrm{PhD}$, Chairman and Head, Veterinary Morphophisiology Department, Anatomy Unit, UFPI, Teresina-PI, Brazil. CNPq Research Productivity Fellowship Level 1D. Conception and design of the study, manuscript writing, critical revision.

\section{ABSTRACT}

PURPOSE: The use of the collared peccary as an experimental model for ischemic nephropathy.

METHODS: A total of 12 collared peccary (Tayassu tajacu) was used and ischemic nephropathy was induced in six of these animals that constituted the experimental group (G1) while the other six formed the control group (G2). Ischemic nephropathy was induced surgically by partial occlusion of the left renal artery. The disease course was assessed by hematological tests, serum chemistry, urinalysis, ultrasound (US) and doppler ultrasound function of the renal artery before induction, and at five, 10, 15 and 20 days after surgery. Twenty days after the occlusion, unilateral nephrectomy and histopathological examination were performed to assess renal morphology. RESULTS: Statistical analysis by Fischer's test showed a significant difference $(p<0.05)$ between the control group and the experimental group. The histopathological examination showed glomerular, tubular and interstitial lesions. In the experimental group, $83.3 \%$ (5/6) showed moderate renal lesions and only $16.7 \%$ (1/6) were classified with no lesions. The ultrasound examination of the right kidney presented statistical difference between day 5 and day 10 post occlusion.

CONCLUSION: The collared peccary as a good experimental model for ischemic renal disease, because it could be manipulated during the research time without death, with health conditions that permit any subsequent procedure for disease therapy.

Key words: Artiodactyla. Kidney Diseases. Ischemia. Models, Animal. 


\section{Introduction}

Obstructive disease of the renal arteries or renovascular disease can produce two different and independent clinical conditions: renovascular hypertension and renal insufficiency $(\mathrm{RI})^{1}$. Renovascular hypertension by clamping the artery was first described by Goldblatt et al. ${ }^{2}$, pioneer in rat models, focused on pathophysiology study and renovascular hypertension treatment. Jacobson $^{3}$, based on studies with hypertension, created the term ischemic nephropathy (IN) considered the standardized model for renal failure induction.

Currently, this technique is mainly used to test treatments for kidney disease or to obtain greater knowledge of the IN mechanisms through the extension of the lesions, as well as explanations for renal artery stenosis, a disease commonly found chronically in humans ${ }^{4}$. The renal ischemia induction model has previously been performed in animals such as rats ${ }^{1}$ and pigs $^{5}$ to analyze the severity and extent of injury and to evaluate therapeutic treatments for secondary hypertension ${ }^{6}$.

Several experiments using stem cell therapy in renal lesions have been made in recent years. A study in rats with mesenchymal stem cell therapy for acute kidney injury induced by ischemia/reperfusion model therapy accelerated renal tissue recovery ${ }^{7}$. The same occurred in a wild rodent (agouti - Dasyprocta prymnolopha) model, in chronic renal injury induced by drugs ${ }^{8}$.

An effective animal model enables the investigation of spontaneous or induced pathological process and resembles the same phenomenon/disease in one or more aspects of the pathological process in humans ${ }^{9}$. The domestic pig is still widely used as an animal model for the study of human disease, and has been shown to be similar to man for biological, anatomic, physiological and nutritional characteristics ${ }^{10}$. However, it has relatively high market value for use in scientific experimentation because of its maintenance. The Suidae model extensively used in various fields of biomedical research, currently, is the mini pig, that is cheaper and easier to maintain under controlled conditions than the domestic pig ${ }^{11}$.

Collared Peccary (Tayassu tajacu) is an ungulate mammal of the Tayassuidae family. The species resemble pigs because they belong to the same order, Artiodactyla, although the pig belong to the Suidae family ${ }^{12,13}$. Currently these animals are being bred in captivity for economic purposes in some regions of Brazil, and are found from Argentina to southeastern United States ${ }^{14}$. It has body length ranging from 75 to $100 \mathrm{~cm}$ and weight 14 to 30 pounds. They are omnivorous animals and adapt to various types of food in captivity. The food items most commonly ingested by peccaries are maize, cassava, pumpkin, sugar cane, balanced feed for pigs or horses (14\% crude protein) and banana pasture (cane, elephant grass, brachiaria and cornstalk ) in specific quantities ${ }^{15-17}$.

The collared peccary has reference values for $\mathrm{CBC}^{18}$, biochemical serum ${ }^{18,19}$, urinalysis $^{18}$ and renal ultrasonography ${ }^{20}$. Knowledge of renal vascular anatomy provides subsidies for surgical techniques, allowing the identification and dissection of the renal pedicle vessels and consequently the partial occlusion of the renal artery. According to Machado et al. ${ }^{21}$, the kidneys of the collared peccary (Tayassu tajacu) have defined renal vascularization in the main renal arteries that branch into sector arteries. The left kidney has triple sectoral arteries and the ventrocaudal artery predominates. Romagnolli et al..$^{22}$ analyzed the renal anatomy of the Tayassu pecari and stated that it (Tayassu peccary) belongs to the same family as the collared peccary, Tayassuidae, renal artery is always single, a fact also observed in collared peccary ${ }^{21}$, wild boar (Sus scrofa $)^{23}$ that belong to superfamily Suidoidae and the domestic pig $^{24}$.

Considering the biology of the collared peccary, their hardiness, disease resistance and good adaptability in captivity, this species could represent a good alternative suidea model for experimental research. The objective of the present study was to establish the collared peccary (Tayassu tajacu) as an experimental model for surgically induced ischemic nephropathy.

\section{Methods}

The protocols used in this experiment were approved by the UFPI Ethics Committee for Experimentation (EAEC Case No. 041/11) and the Authorization and Biodiversity Information System-SISBIO (Case No. 33058).

This experiment was performed using peccary (Tayassu tajacu) males reared in the Center for the Study and Preservation of Wild Animals - NEPPAS (registration at the Brazilian Institute of Environment and Renewable Natural Resources, IBAMA, No. 02/08-618) of the Federal University of Piaui (UFPI).

\section{Experimental design}

A total of 12 collared peccary (Tayassu tajacu) was used and ischemic nephropathy was induced in six of these animals that constituted the experimental group (G1) while the other six formed the control group (G2). The kidneys of the animals (G1) were evaluated by hematologic tests, urinalysis, ultrasound and Doppler ultrasound before induction, and repeated at five, 10, 15 and 20 days after induction. The animals were subjected to renal ischemia by partial occlusion of the renal artery, and 20 days later unilateral left radical nephrectomy was performed. The control 
group (G2), also consisting of six collared peccary, the left kidneys were collected by unilateral total nephrectomy for histopathology.

Animals considered clinically healthy were identified , weighed, kept in NEPPAS in individual stalls cleaned daily, fed commercial diet (minimum 16\% crude protein, 3.03\% ether extract - 3.03\% 5.5\% - fibrous matter, 5\% ash, 7.5\% calcium $1.3 \%$ and phosphorus $-0.7 \%$ ), and corn, fruits, tubers and water ad libitum. The weight of the animals ranged from 12 to $15 \mathrm{~kg}$.

\section{Anesthesia}

In all procedures, the animals were restrained chemically, after a 24-hour fasting period 12 hours without liquid, in the morning with a combination of $15 \mathrm{mg} / \mathrm{kg}$ ketamine (Dopalen ${ }^{\circledR}$ ) associated with $1 \mathrm{mg} / \mathrm{kg}$ maleate midazolam (Dormire ${ }^{\circledR}$ ) using a pneumatic blowpipe dart designed by (DistInject ${ }^{\mathbb{R}}$ ).

For the surgical procedure, after chemical restraint, the animals were transported to the operating room of the Veterinary Teaching Hospital (HVU), Center for Agricultural Sciences, UFPI, where the cephalic vein was cannulated with a $20 \mathrm{G}$ catheter and were maintained with infusion of Ringer's lactate. They were induced to inhalational anesthesia with $5 \mathrm{mg} / \mathrm{kg}$ propofol $\left(\operatorname{Propovan}^{\circledR}\right)$, intubated with a 7.5 endotracheal tube and maintained with isoflurane (Isoflurane ${ }^{\circledR}$ ) diluted in $100 \% \mathrm{O}_{2}$. The animals were monitored throughout the trans-operative period by cardiac monitor and pulse oximeter.

\section{Sonographic evaluation and Doppler function}

The bilateral kidney morphological evaluation was performed by ultrasound equipment Chison Q6 probe microconvexa 6-8 MHz and 10-12 MHz probe. The values kidney size, length and diameter and morphological description of echogenicity patterns were measured. Doppler velocity values of flow and vascular resistivity index were observed. The examination was performed again at five, 10 and 20 days after inducing renal injury.

\section{Laboratory evaluation}

For urinalysis, urine was collected by ultrasound-guided cystocentesis to perform the analysis in a hand refractometer (Quimis Q667 - 5), tape urinalysis (Uriquest Vet Plus the Labtest). Physical, chemical and sediment urine aspects were evaluated, along with other findings of urinalysis.

To check the renal function of the animals, $5 \mathrm{ml}$ of peripheral blood were collected from the cephalic vein punctured with a sterile $10 \mathrm{~mL}$ syringe attached to a $23 \mathrm{G}$ needle. The blood was centrifuged at 3000 revolutions per minute (rpm) for 10 minutes to remove the serum and perform serum biochemical dosage (Doles model D- 250) of urea, creatinine, calcium, phosphorus, potassium, and alkaline phosphatase.

\section{Surgical induction of renal ischemia and nephrectomy}

Ischemic nephropathy was induced by clamping the renal artery (Figure 1). After shaving the abdomen and skin antisepsis with $2 \%$ chlorhexidine and $1 \%$ iodine alcohol, the hind animals underwent laparotomy in the left flank. The skin was incised in dorsoventral direction and the external, internal oblique and transverse oblique muscles were separated. The transverse fascia and peritoneum were incised, and with the aid of Farebeuf retractors, the left kidney was visualized and the renal pedicle identified. The left renal artery was dissected and isolated with the aid of 0 cotton yarn, and after putting up a parallel $24 \mathrm{G}$ hypodermic needle $(20 \times 0.55)$ renal artery occlusion proceeded by suture around the renal artery and superimposed on the same needle. After the surgical knot, the needle was withdrawn, thus promoting partial occlusion of the renal artery and standardization of the technique for all animals. Then followed the abdomen closed with the approximate muscles separated by in X with Nylon 3-0 and skin, separated with Nylon 3-0 single sutures.

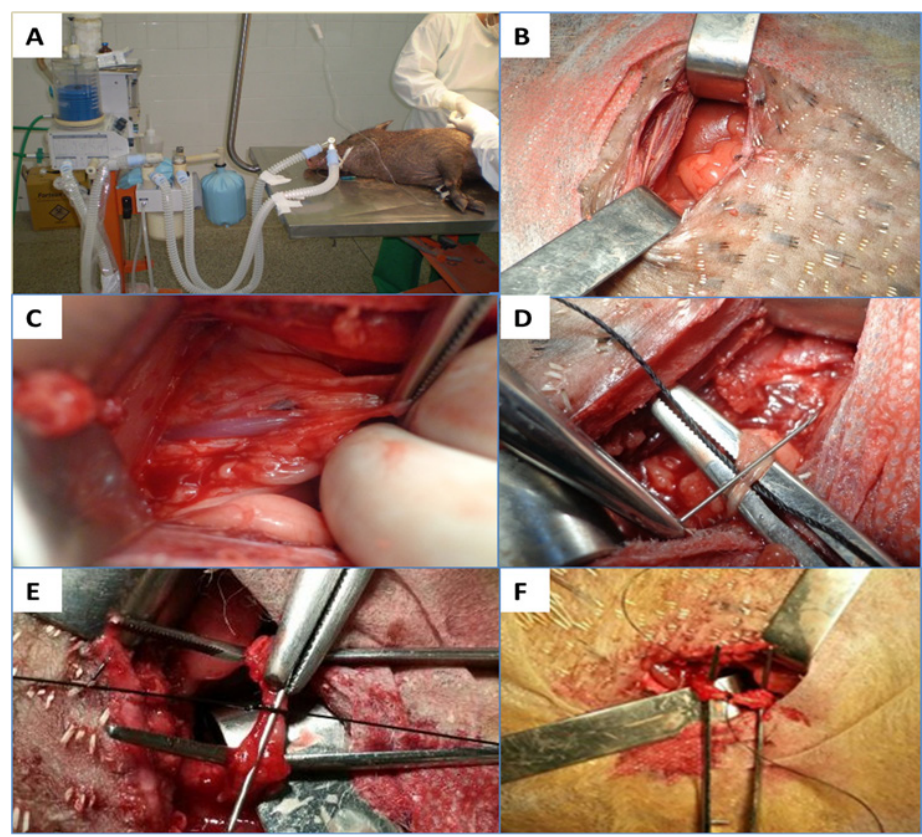

FIGURE 1 - A. Collared peccary (Tayassu tajacu) kept under inhalation anesthesia in the operating room of the HVU, UFPI. B. Exposure of the left kidney by the left flank laparotomy with removal of internal, external peritoneum and transverse, internal and external oblique muscles. C. View of the left renal pedicle for dissection of the renal artery. D. Hypodermic needle placed parallel to the left renal artery and anchoring cotton yarn 0 . E. Surgical knot for partial occlusion of the renal artery. F. Arterial occlusion completed with the withdrawal of the hypodermic needle allowing the passage of reduced blood flow. 
For the postoperative care the peccaries received 40.000 IU benzantine benzylpenicillin $\left(\right.$ Bepeben $\left.^{\circledR}\right)$, flunixin meglumine $\left(\right.$ Banamine $\left.^{\circledR}\right), 2 \mathrm{mg} / \mathrm{kg}$ dipyrone $\left(\right.$ Algive $\left.^{\circledR}\right)$ and $25 \mathrm{mg} / \mathrm{kg}$ tramadol $\left(\right.$ Tramadon $\left.^{\circledR}\right)$. For topical wound treatment, rifamycin spray was used (Rifocina ${ }^{\circledR}$ ) and healing ointment $\left(\right.$ Alantol $\left.^{\circledR}\right)$. Twenty days after inducing partial ischemic nephropathy, total unilateral nephrectomy was performed, using the same anesthetic protocol. A laparotomy was performed through the left flank of the animals. The renal pedicle was identified and dissected to separate the artery, renal vein and ureter, performing a dual ligation of these elements, sectioned, there between, and then the kidney was taken out of the cavity. Subsequently laparorrhaphy, dressing and postoperative care were performed, as already indicated in the surgical induction of nephropathy.

\section{Renal histopathological evaluation}

For histopathological analysis, fragments of the cortex and medulla of the injured kidney, $5 \mathrm{~mm}$ thick, fixed in Bouin for 24 hours, processed and embedded in paraffin, were collected, according to the routine technique, in the Animal Pathology Laboratory, UFPI. Prepared $5 \mu \mathrm{m}$ thick cuts stained with hematoxylin-eosin, Masson's trichrome staining of fibrous connective tissue, PAS (Periodic Acid Schiff) and PAMS (periodic acid - Metamina Silver) for evaluation of basal cell membranes.

\section{Statistical analysis}

Renal lesions were identified and classified according to adaptation of the methodology described by Konopka et al. ${ }^{1}$. Intensity levels were classified into four grades: absent, mild, moderate and intense, and statistical analysis was assigned values of $0,1,2,3$, respectively. The qualitative responses relating to the examination were analyzed in $2 \times 2$ contingency and the Fisher exact test table. The statistical objective was to compare the animal before (day 0 ) and after induction (20 days) to verify the effectiveness of the collared peccary as an animal model for induced nephropathy.
The data obtained in serum biochemistry, complete blood count, ultrasound (US), US Doppler vascular urinalysis and quantitative analyzes were analyzed by parametric statistics in a completely randomized design and means were compared by Student's t test. Qualitative responses found in urinalysis were replaced by scores according to Belommo et al..$^{25}$ and the nonparametric Kruskal-Wallis test was used. All statistical analyzes were performed by the Graph Prism 6.0 statistical program. A significance level was adopted of $\mathrm{p}<0.05$.

\section{Results}

The results for the induction of ischemic nephropathy in collared peccary (Tayassu tajacu) showed no systemic changes, the animals remained clinically healthy. However, the obstructed kidney had focused alterations. The animal model was resistant to multiple surgical procedures and secondary infections and also presented rapid healing. There were no animal deaths in this experiment. Regarding the serum chemistry values related to urea, creatinine, calcium, phosphorus, potassium, and alkaline phosphatase were not statistically different $(p>0.05)$ by the Student $\mathrm{t}$ test (Table 1) and the animals did not show change in the values after induction at five, 10, 15 and 20 days compared to healthy animals (day 0).

As for the values of $\mathrm{CBC}$, white and red blood were evaluated (Table 2), again the averages did not differ between days $5,10,15$ and 20 .

Means followed by the same letter on the same line do not differ statistically ( $p>0.05$ ) when compared between days 0 , $5,10,15$ and 20 days, by comparison of means and Student $t$ test.

In the urinalysis analyses, comprising urine physical, chemical and sediment examination (Table 3) and serum biochemistry and blood count, there was no significant difference between the experimental and control groups for quantitative assessments and regarding the urinalysis group, there were no differences between days evaluated by the Student $t$ test at $5 \%$ significance.

TABLE 1 - Values of biochemical tests in collared peccary before and after induction of ischemic nephropathy.

\begin{tabular}{l|l|l|l|l|l}
\hline Evaluated data & 0 day & 5 days & 10 days & 15 days & 20 days \\
\hline Urea $(\mathrm{mg} / \mathrm{dL})$ & $24.20 \pm 4.55^{\mathrm{a}}$ & $23.48 \pm 2.40^{\mathrm{a}}$ & $26.86 \pm 3.36^{\mathrm{a}}$ & $37.66 \pm 13.49^{\mathrm{a}}$ & $31.90 \pm 4.64^{\mathrm{a}}$ \\
\hline Creatinine (mg/dL) & $1.96 \pm 0.22^{\mathrm{a}}$ & $2.18 \pm 0.34^{\mathrm{a}}$ & $2.55 \pm 0.44^{\mathrm{a}}$ & $2.63 \pm 0.32^{\mathrm{a}}$ & $2.33 \pm 0.31^{\mathrm{a}}$ \\
\hline Calcium (mg/dL) & $9.92 \pm 0.59^{\mathrm{a}}$ & $9.64 \pm 0.74^{\mathrm{a}}$ & $9.62 \pm 1.11^{\mathrm{a}}$ & $9.40 \pm 0.96^{\mathrm{a}}$ & $8.54 \pm 0.85^{\mathrm{a}}$ \\
\hline Phosphorus (mg/dL) & $14.89 \pm 5.16^{\mathrm{a}}$ & $9.82 \pm 3.58^{\mathrm{a}}$ & $10.14 \pm 4.60^{\mathrm{a}}$ & $7.28 \pm 0.62^{\mathrm{a}}$ & $7.32 \pm 0.72^{\mathrm{a}}$ \\
\hline Potassium (mmol/L) & $4.27 \pm 0.27^{\mathrm{a}}$ & $3.89 \pm 0.29^{\mathrm{a}}$ & $2.74 \pm 0.43^{\mathrm{a}}$ & $3.20 \pm 0.98^{\mathrm{a}}$ & $3.92 \pm 0.58^{\mathrm{a}}$ \\
\hline AF (UI/L) & $222.03 \pm 60.47^{\mathrm{a}}$ & $169.48 \pm 32.26^{\mathrm{a}}$ & $143.12 \pm 31.65^{\mathrm{a}}$ & $167.62 \pm 39.59^{\mathrm{a}}$ & $188.17 \pm 53.04^{\mathrm{a}}$ \\
\hline
\end{tabular}

*Means followed by the same letter on the same line do not differ statistically $(\mathrm{p}>0.05)$ in the collared peccary in biochemical analyses compared between days $0,5,10,15$ and 20 days, by comparison of means and the Student $t$ test. FA; Alkaline phosphatase. 
TABLE 2 - WBC count in (Tayassu tajacu) before and after inducing ischemic nephropathy surgical renal artery occlusion.

\begin{tabular}{|c|c|c|c|c|c|}
\hline Evaluated data & 0 day & 5 days & 10 days & 15 days & 20 days \\
\hline RBCs $\left(\times 10^{6} / \mu \mathrm{L}\right)$ & $7.12 \pm 0.73^{\mathrm{a}}$ & $5.65 \pm 0.16^{a}$ & $6.80 \pm 0.49^{a}$ & $6.62 \pm 0.58^{a}$ & $6.54 \pm 0.34^{\mathrm{a}}$ \\
\hline Hemoglobin ( $\mathrm{g} / \mathrm{dL})$ & $12.49 \pm 0.59^{\mathrm{a}}$ & $10.65 \pm 0.26^{\mathrm{a}}$ & $12.40 \pm 0.51^{\mathrm{a}}$ & $12.00 \pm 1.17^{a}$ & $11.13 \pm 0.50^{a}$ \\
\hline Hematocrit (\%) & $35.77 \pm 1.17^{\mathrm{a}}$ & $29.78 \pm 1.49^{a}$ & $35.47 \pm 2.07^{a}$ & $32.68 \pm 2.12^{a}$ & $32.73 \pm 1.81^{a}$ \\
\hline MCV (fl) & $51.80 \pm 3.15^{\mathrm{a}}$ & $52.93 \pm 1.11^{\mathrm{a}}$ & $52.83 \pm 2.75^{a}$ & $50.05 \pm 3.31^{a}$ & $50.48 \pm 2.82^{a}$ \\
\hline $\mathrm{MCH}(\mathrm{pg})$ & $18.07 \pm 1.27^{\mathrm{a}}$ & $18.93 \pm 0.70^{\mathrm{a}}$ & $18.52 \pm 1.05^{\mathrm{a}}$ & $18.33 \pm 1.66^{\mathrm{a}}$ & $17.17 \pm 1.02^{a}$ \\
\hline $\mathrm{MCHC}(\%)$ & $34.90 \pm 1.20^{a}$ & $36.00 \pm 2.01^{a}$ & $35.18 \pm 1.30^{a}$ & $36.63 \pm 2.11^{a}$ & $34.12 \pm 1.11^{a}$ \\
\hline Platelets $\left(\times 10^{3} \mathrm{~mm}^{3}\right)$ & $321.17 \pm 65.94^{\mathrm{a}}$ & $358.75 \pm 45.06^{a}$ & $329.00 \pm 29.76^{a}$ & $341.75 \pm 56.8^{\mathrm{a}}$ & $441.66 \pm 66.44^{\mathrm{a}}$ \\
\hline 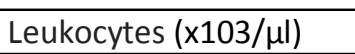 & $15.43 \pm 4.77^{\mathrm{a}}$ & $14.15 \pm 2.58^{\mathrm{a}}$ & $22.47 \pm 4.63^{\mathrm{a}}$ & $18.95 \pm 3.25^{a}$ & $14.22 \pm 2.49^{\mathrm{a}}$ \\
\hline Myelocytes (\%) & $0.00 \pm 0.00^{\mathrm{a}}$ & $0.00 \pm 0.00^{\mathrm{a}}$ & $0.00 \pm 0.00^{\mathrm{a}}$ & $0.00 \pm 0.00^{\mathrm{a}}$ & $0.00 \pm 0.00^{\mathrm{a}}$ \\
\hline Metamyelocytes (\%) & $0.00 \pm 0.00^{\mathrm{a}}$ & $0.00 \pm 0.00^{\mathrm{a}}$ & $0.00 \pm 0.00^{a}$ & $0.00 \pm 0.00^{\mathrm{a}}$ & $0.00 \pm 0.00^{a}$ \\
\hline Rods (\%) & $0.00 \pm 0.00^{\mathrm{a}}$ & $0.00 \pm 0.00^{\mathrm{a}}$ & $0.00 \pm 0.00^{\mathrm{a}}$ & $0.00 \pm 0.00^{\mathrm{a}}$ & $0.17 \pm 0.17^{\mathrm{a}}$ \\
\hline Segmented (\%) & $33.00 \pm 6.40 \mathrm{a}$ & $55.50 \pm 5.19^{a}$ & $46.67 \pm 5.60^{a}$ & $47.75 \pm 6.10^{\mathrm{a}}$ & $54.17 \pm 7.35^{\mathrm{a}}$ \\
\hline Eosinophils (\%) & $4.50 \pm 2.14^{a}$ & $4.00 \pm 2.27^{\mathrm{a}}$ & $3.33 \pm 1.23^{\mathrm{a}}$ & $2.00 \pm 0.91^{\mathrm{a}}$ & $1.67 \pm 0.71^{\mathrm{a}}$ \\
\hline Basophils (\%) & $0.00 \pm 0.00^{\mathrm{a}}$ & $0.00 \pm 0.00^{\mathrm{a}}$ & $0.00 \pm 0.00^{a}$ & $0.00 \pm 0.00^{\mathrm{a}}$ & $0.00 \pm 0.00^{\mathrm{a}}$ \\
\hline Typical Lymphocytes(\%) & $61.50 \pm 5.44^{\mathrm{a}}$ & $39.25 \pm 4.82^{a}$ & $48.83 \pm 4.63^{a}$ & $48.00 \pm 6.98^{\mathrm{a}}$ & $42.67 \pm 7.04^{\mathrm{a}}$ \\
\hline Monocytes (\%) & $1.00 \pm 0.37^{\mathrm{a}}$ & $1.25 \pm 0.25^{\mathrm{a}}$ & $1.17 \pm 0.40^{\mathrm{a}}$ & $1.25 \pm 0.75^{\mathrm{a}}$ & $1.33 \pm 0.61^{\mathrm{a}}$ \\
\hline
\end{tabular}

TABLE 3 - Analysis of urine analysis peccary (Tayassu tajacu) before and after submission of ischemic nephropathy renal artery occlusion.

\begin{tabular}{l|c|c|c|c|c}
\hline Evaluated data & 0 day & 5 days & 10 days & 15 days & 20 days \\
\hline Density & $1017 \pm 4.094^{\mathrm{a}}$ & $1012.8 \pm 2.24^{\mathrm{a}}$ & $1019.5 \pm 1.89^{\mathrm{a}}$ & $1008.66 \pm 1.76^{\mathrm{a}}$ & $1023.6 \pm 8.65^{\mathrm{a}}$ \\
\hline Ph & $6.75 \pm 0.65^{\mathrm{a}}$ & $7.2 \pm 0.73^{\mathrm{a}}$ & $5.75 \pm 0.75^{\mathrm{a}}$ & $7.66 \pm 0.33^{\mathrm{a}}$ & $7.1 \pm 0.4^{\mathrm{a}}$ \\
\hline Glucose $(\mathrm{mg} / \mathrm{dl})$ & $0 \pm 0^{\mathrm{a}}$ & $0 \pm 0^{\mathrm{a}}$ & $0 \pm 0^{\mathrm{a}}$ & $0 \pm 0^{\mathrm{a}}$ & $0 \pm 0^{\mathrm{a}}$ \\
\hline Ketone $(\mathrm{mg} / \mathrm{dl})$ & $0 \pm 0^{\mathrm{a}}$ & $0 \pm 0^{\mathrm{a}}$ & $0 \pm 0^{\mathrm{a}}$ & $0 \pm 0^{\mathrm{a}}$ & $0 \pm 0^{\mathrm{a}}$ \\
\hline Nitrite $(\mathrm{mg} / \mathrm{dl})$ & $0 \pm 0^{\mathrm{a}}$ & $0 \pm 0^{\mathrm{a}}$ & $0 \pm 0^{\mathrm{a}}$ & $0 \pm 0^{\mathrm{a}}$ & $0 \pm 0^{\mathrm{a}}$ \\
\hline Color & $1.5 \pm 0.34^{\mathrm{a}}$ & $1 \pm 0^{\mathrm{a}}$ & $2 \pm 0.70^{\mathrm{a}}$ & $1 \pm 0^{\mathrm{a}}$ & $1.6 \pm 0.6^{\mathrm{a}}$ \\
\hline Aspect & $0 \pm 0^{\mathrm{a}}$ & $0.4 \pm 0.4^{\mathrm{a}}$ & $0 \pm 0^{\mathrm{a}}$ & $0 \pm 0^{\mathrm{a}}$ & $0 \pm 0^{\mathrm{a}}$ \\
\hline Cells & $0.5 \pm 0.22^{\mathrm{a}}$ & $0.4 \pm 0.29^{\mathrm{a}}$ & $0.5 \pm 0.28^{\mathrm{a}}$ & $0 \pm 0^{\mathrm{a}}$ & $0.2 \pm 0.2^{\mathrm{a}}$ \\
\hline RBCS & $0 \pm 0^{\mathrm{a}}$ & $0 \pm 0^{\mathrm{a}}$ & $1.25 \pm 0.62^{\mathrm{a}}$ & $0 \pm 0^{\mathrm{a}}$ & $0 \pm 0^{\mathrm{a}}$ \\
\hline Leukocytes & $0 \pm 0^{\mathrm{a}}$ & $0 \pm 0^{\mathrm{a}}$ & $0 \pm 0^{\mathrm{a}}$ & $0 \pm 0^{\mathrm{a}}$ & $0 \pm 0^{\mathrm{a}}$ \\
\hline Protein $(\mathrm{mg} / \mathrm{dl})$ & $20 \pm 10^{\mathrm{a}}$ & $36 \pm 6^{\mathrm{a}}$ & $30 \pm 0^{\mathrm{a}}$ & $40 \pm 10^{\mathrm{a}}$ & $50 \pm 13.78^{\mathrm{a}}$ \\
\hline Cylinders & $0.5 \pm 0.5^{\mathrm{a}}$ & $0.4 \pm 0.24^{\mathrm{a}}$ & $0.5 \pm 0.5 \mathrm{a}$ & $0.33 \pm 0.33^{\mathrm{a}}$ & $0.4 \pm 0.24^{\mathrm{a}}$ \\
\hline Mucus & $0 \pm 0^{\mathrm{a}}$ & $0 \pm 0^{\mathrm{a}}$ & $0 \pm 0^{\mathrm{a}}$ & $0 \pm 0^{\mathrm{a}}$ & $0 \pm 0^{\mathrm{a}}$ \\
\hline Bacteria & $0 \pm 0^{\mathrm{a}}$ & $0.6 \pm 0.6^{\mathrm{a}}$ & $0 \pm 0^{\mathrm{a}}$ & $0 \pm 0^{\mathrm{a}}$ & $0 \pm 0^{\mathrm{a}}$ \\
\hline Crystals & $1.33 \pm 0.61^{\mathrm{a}}$ & $1.2 \pm 0.58^{\mathrm{a}}$ & $1.5 \pm 0.86^{\mathrm{a}}$ & $1 \pm 1^{\mathrm{a}}$ & $0.8 \pm 0.58^{\mathrm{a}}$ \\
\hline
\end{tabular}

Qualitative data were replaced by scores and analyzed by the Kruskall- Wallis test at 5\% significance level, the means were shown to be equal before and after treatment among the days of the experiment (Table 3). Physical examination showed pale yellow color, straw, gold and cloudy, with a predominance of light yellow color and usually clear urine. The $\mathrm{pH}$ of the animal's urine remained close to neutrality, ranging between acid and basic character, but without significant difference. Ketones, nitrites, glucose were found, as well as leukocytes. In all periods there were findings related to epithelial cell desquamation and transition.

Urinary evaluation showed proteinuria, casts (granular cylinders) and crystalluria (crystals of oxalate monohydrate and dihydrate calcium, triple phosphate and sodium urate) in all the evaluation periods of the experiment. Mucus was not observed in any period, and bacteria were found in only one animal, and only on day 5 , indicating urinary tract infection that was treated with antibiotics. 
Means followed by the same letter on the same line do not differ statistically ( $\mathrm{p}>0.05)$ when compared between days 0 , $5,10,15$ and 20, by comparison of means and the Student $t$ test.

Table 4 shows the length and diameter of the kidneys, obtained by ultrasound. In the Doppler examination of normal renal blood flow proved partial occlusion of the renal artery as shown in Figure 2, in which part of the blood coming to the renal hilum can be seen that irrigates the interlobular and arched arteries.

Means followed by the same letter on the same column do not differ statistically ( $\mathrm{p}>0.05$ ) when compared between 0,5 , 10, 15 and 20 days, by comparison of means and the Student $t$ test. Diam: Diameter; RI: resistivity index; BF: blood flow.

In the kidneys of animals in the control group, there was preserved size, contours and regular edges. The corticomedullary ratio was preserved with homogeneous echotexture in the cortical parenchyma and the renal pelvis showed normal pattern. Examination by color Doppler showed a blade flow pattern close to the renal artery, without tortuosity, stenosis or obstruction. Spectral Doppler showed normal pattern systolic and diastolic waves with preserved speeds (the standard for the species was reached) and preserved vascular resistance index (Figure 2C) (Table 4).

Post- induction and normal kidneys revealed topographical syntopy in all the animals. There was loss of heterogeneity and coarse echotexture, characterized by diffuse hypoechoic foci through cortical parenchyma (Figure 2A). The overall echogenicity was shown to be increased in relation to the spleen (left kidney near isoechogenic) and liver (isoechogenic or hyperechoic right kidney). There was loss of corticomedullary ratio, showing a hyperechoic halo of crystal deposition in the corticomedullary border (Figure $2 \mathrm{~B}$ ). The vascular flow proved to be reduced when examined by color Doppler, with hypoperfusion and lower arcuate arteries (obstruction) (Figure 2D). An increase was identified in vascular impedance, increased resistivity rates, compared to normal and pre-induction, showing decrease in diastolic and high systolic peak flow.

TABLE 4 - Sonographic and Doppler vascular kidney examinations before and after inducing ischemic nephropathy surgical renal artery occlusion in collared peccary.

\begin{tabular}{r|c|c|c|c|c|c|c|c}
\hline & \multicolumn{5}{|c|}{ Left Kidney } & \multicolumn{4}{c}{ Right Kidney } \\
\hline Days & Length $(\mathrm{mm})$ & Diam $(\mathrm{mm})$ & $\mathrm{RI}$ & $\mathrm{BF}(\mathrm{cm} / \mathrm{s})$ & Length $\left.(\mathrm{mm})^{\mathrm{a}}\right)$ & Diam $(\mathrm{mm})$ & $\mathrm{RI}$ & $\mathrm{BF}(\mathrm{cm} / \mathrm{s})$ \\
\hline 0 & $54.81 \pm 1.58^{\mathrm{a}}$ & $26.96 \pm 2.21^{\mathrm{a}}$ & $0.41 \pm 0.01^{\mathrm{a}}$ & $25.86 \pm 0.81^{\mathrm{a}}$ & $59.44 \pm 0.81^{\mathrm{abc}}$ & $24.77 \pm 0.79^{\mathrm{a}}$ & $0.38 \pm 0.02^{\mathrm{a}}$ & $26.30 \pm 2.06^{\mathrm{a}}$ \\
\hline 5 & $56.07 \pm 1.46^{\mathrm{a}}$ & $28.20 \pm 2.18^{\mathrm{a}}$ & $0.43 \pm 0.01^{\mathrm{a}}$ & $26.90 \pm 0.86^{\mathrm{a}}$ & $60.38 \pm 0.77^{\mathrm{b}}$ & $26.11 \pm 0.61^{\mathrm{a}}$ & $0.42 \pm 0.01^{\mathrm{a}}$ & $28.00 \pm 1.70^{\mathrm{a}}$ \\
\hline 10 & $55.31 \pm 1.55^{\mathrm{a}}$ & $27.47 \pm 2.29^{\mathrm{a}}$ & $0.45 \pm 0.01^{\mathrm{a}}$ & $27.88 \pm 0.60^{\mathrm{a}}$ & $61.16 \pm 0.83^{\mathrm{c}}$ & $26.79 \pm 0.54^{\mathrm{a}}$ & $0.46 \pm 0.01^{\mathrm{a}}$ & $28.76 \pm 1.71^{\mathrm{a}}$ \\
\hline 20 & $52.84 \pm 1.54^{\mathrm{a}}$ & $24.69 \pm 2.16^{\mathrm{a}}$ & $0.47 \pm 0.01^{\mathrm{a}}$ & $26.18 \pm 1.15^{\mathrm{a}}$ & $60.65 \pm 0.79^{\mathrm{abc}}$ & $26.27 \pm 0.62^{\mathrm{a}}$ & $0.44 \pm 0.01^{\mathrm{a}}$ & $28.53 \pm 1.70^{\mathrm{a}}$ \\
\hline
\end{tabular}

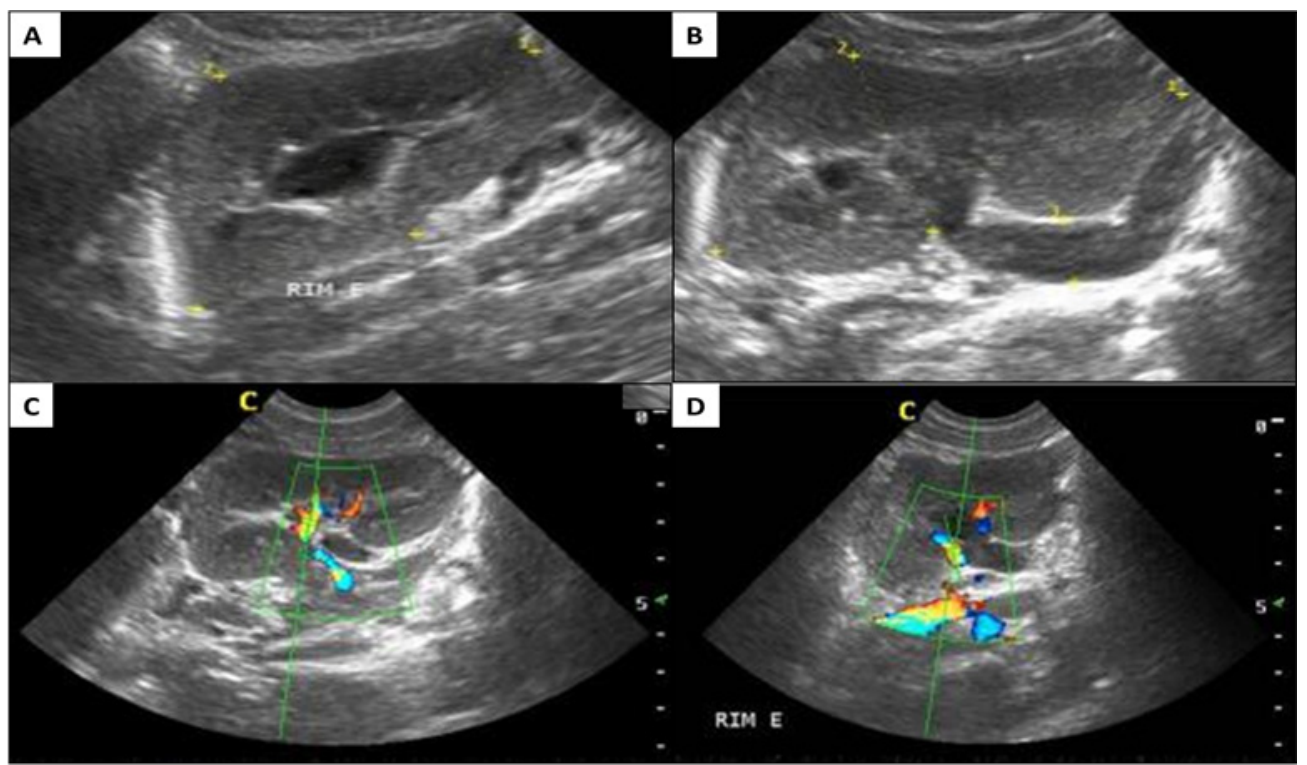

FIGURE 2 - A and B. Collared peccary ultrasound of the left kidney (Tayassu tajacu) post-induction of partial occlusion. C. Doppler left kidney, normal flow. D. Doppler after induction of renal partial occlusion of the left renal artery. 
Among the findings, the renal length increased significantly $(p<0.05)$ (Table 4$)$ of the right kidney on the 10 th day post-ischemic induction, compared to day 5 (Figure 3A), but no differences were presented in renal length and diameter in other periods. However, means analysis showed a slight reduction in the length and diameter of the left kidney from day 10 and the decrease continued until the 20th day post- induction (Figure 3D).

The spectral Doppler US showed values for the blood flow velocity in the renal artery and resistance index. These parameters on the assessment days showed no statistical differences (Table 4). The resistivity index (RI) of the left kidney, despite not showing statistical difference, maintained a slight increase until the 20th day after induction. The right RI had a similar reaction, but there was a slight decrease on day 20 , thus differing from the partially obstructed contralateral kidney (Figure 3B). The right artery blood right flow velocity $(\mathrm{cm} / \mathrm{s})$, even though there was no significant difference, showed a slight increase after partial occlusion, a fact that also occurred in the left artery, but speed decreased from 10 days post-occlusion until the 20th day (Figure 3C).
Histopathological examination of the kidneys of animals in the experimental group showed significantly more severe injuries than the control group $(p<0.05)$, demonstrating that the technique enabled the induction of ischemic nephropathy in the test model. In $83.3 \%(5 / 6)$ of the animals in the experimental group glomerular, tubular and interstitial lesions in moderate degree were observed in the cortical and medullary regions of the kidney and these lesions did not occur in only $16.7 \%(1 / 6)$.

The main changes in the renal corpuscles were atrophy of glomerulus with nuclear pyknosis of some glomerular cells, indicating glomerular necrosis or apoptosis (Figure 4B). The urinary space (Bowman's space) was $16.7 \%$ (1/6) of the control group and $33.3 \%$ $(2 / 6)$ in the experimental group, a discrete amount of proteinaceous material was observed (Figure 4A). In $83.3 \%(5 / 6)$ of the animals there was renal ischemia thickening of the glomerular capillary basement membrane, increase in the urinary space (Figure 4D), glomerular sclerosis in 100\% (6/6) and thickening glomerular capsule was observed in $83.3 \%$ (5/6) (Figure 4F). The proximal and distal convoluted tubules and straight nephron loop tubules also had lesions (Figure $4 \mathrm{G}$ and $\mathrm{H}$ ).

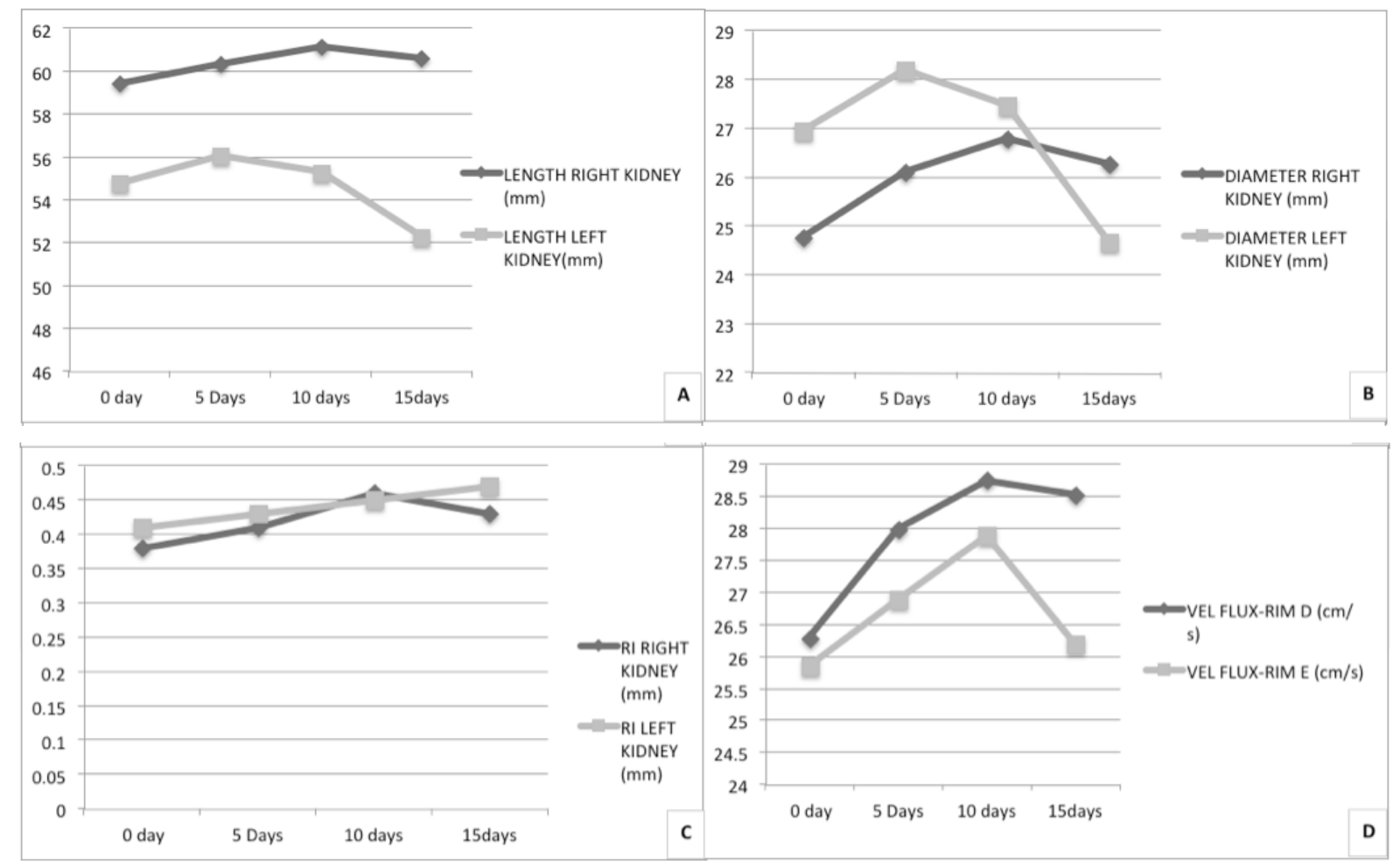

FIGURE 3 - Analysis of values for the kidney length (A), resistivity index (RI) (B), blood flow (C) and diameter (D) before (day 0) and after partial occlusion of the left renal artery $(5,10$ and 20 days) in collared peccary. 

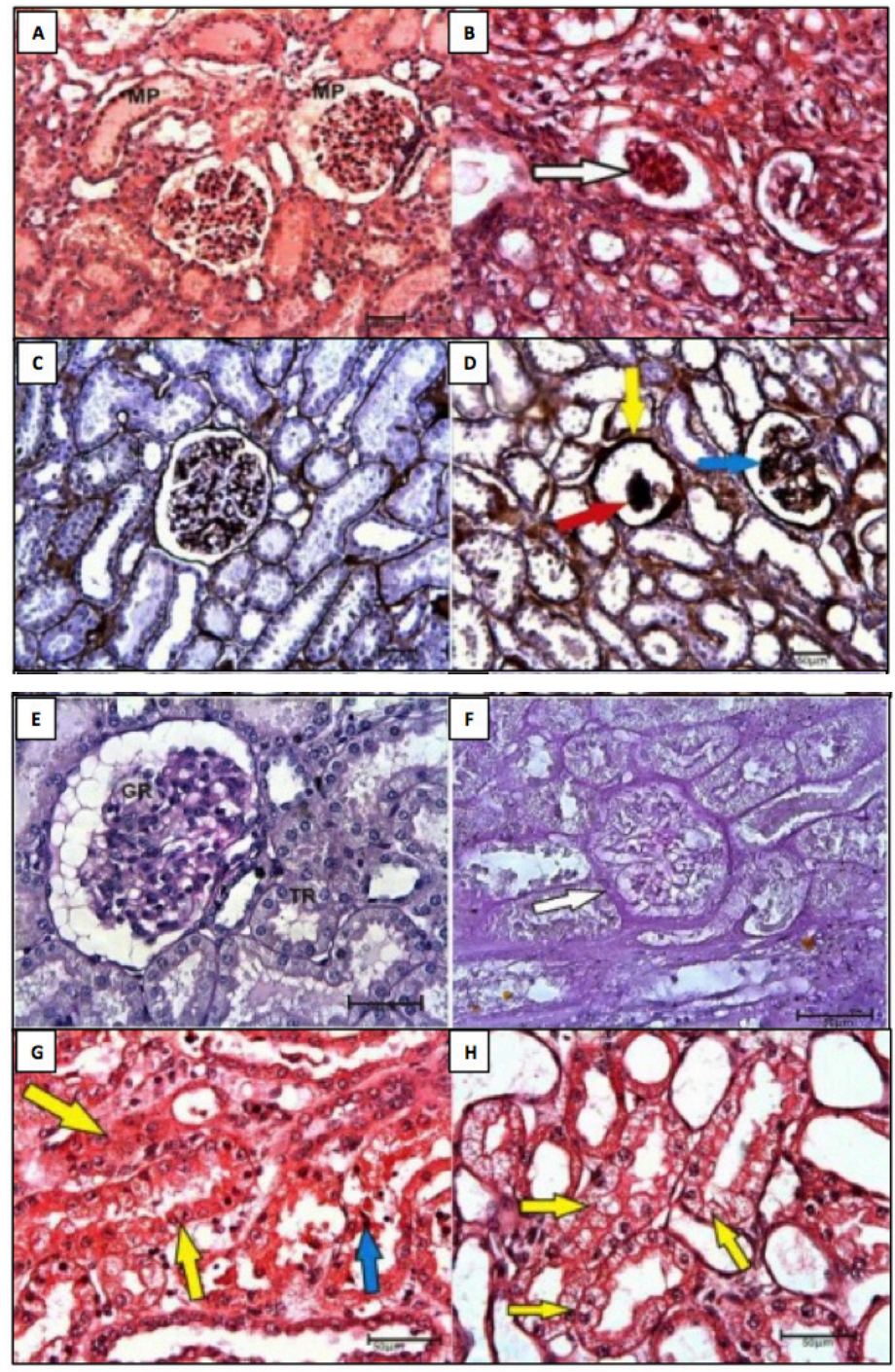

FIGURE 4 - Photomicrograph of collared peccary (Tayassu tajacu) kidney. A. Normal kidney showing intact glomeruli and renal tubules. Coloration: HE. Magnification: x200. MP: proteinaceous material in the urinary and intratubular space. B. Kidney after partial induction of ischemic nephropathy. Atrophy of the glomeruli and increased urinary space (arrow). Coloration: HE. Magnification: x400. Normal. C. Kidney. Basement membranes and mesangial matrix stained black. Coloration: PAMS Increase: x200. D. Rim after partial induction of ischemic nephropathy. Thickening of the glomerular capillary basement membrane (blue arrow) and glomerular capsule (yellow arrow); Atrophy of glomerulus (red arrow). Coloration: PAMS Increase: x200. E. Normal kidney showing the normality of the glomerular membrane, capsular and tubular capillaries. Staining: PAS, magnification: x400. GR: renal glomerulus; TR: renal tubule. F. Kidney after partial induction of ischemic nephropathy. Thickening of the glomerular basement membrane capsule (arrow). Staining: PAS, magnification: $x 400$. G. Degeneration of tubular epithelial cells (yellow arrows) with pyknotic nuclei (blue arrow). Coloration: HE, magnification: $\mathrm{x} 400$. H. Tubular degeneration (yellow arrows) Coloration: HE, magnification: x400.

Renal tubule tubular atrophy, degeneration and necrosis were found in $83.3 \%(5 / 6)$. In the animals of the experimental group, the cells had pyknotic nuclei, increased cytoplasmic eosinophilia and occasionally intratubular cellular debris (Figure $4 \mathrm{H})$. In relation to the tubular basement membrane thickening was $83.3 \%(5 / 6)$, rupture $66.7 \%(4 / 6)$ (Figure 5A). In $66.7 \%$ (4/6) a variable amount of intratubular proteinaceous material was observed classified as hyaline casts (Figure 5B). In 83.3\% $(5 / 6)$ in some tubules ectasia was identified of the cortical region of the kidney (Figure 5G and $\mathrm{H}$ ). Among the interstitial injuries, periglomerular interstitial nephritis was observed in $83.3 \%(5 / 6)$ cases, demonstrated by the presence of inflammatory infiltrate, consisting of macrophages, lymphocytes and plasma cells (Figure 5H), severe interstitial fibrosis in 83.3\% (5/6) (Figure 5D) congestion in $33.3 \%(2 / 6)$, interstitial edema in $33.3 \%(2 / 6)$ and hemorrhage areas in $167 \%(1 / 6)$ (Figure 5E, 5F).
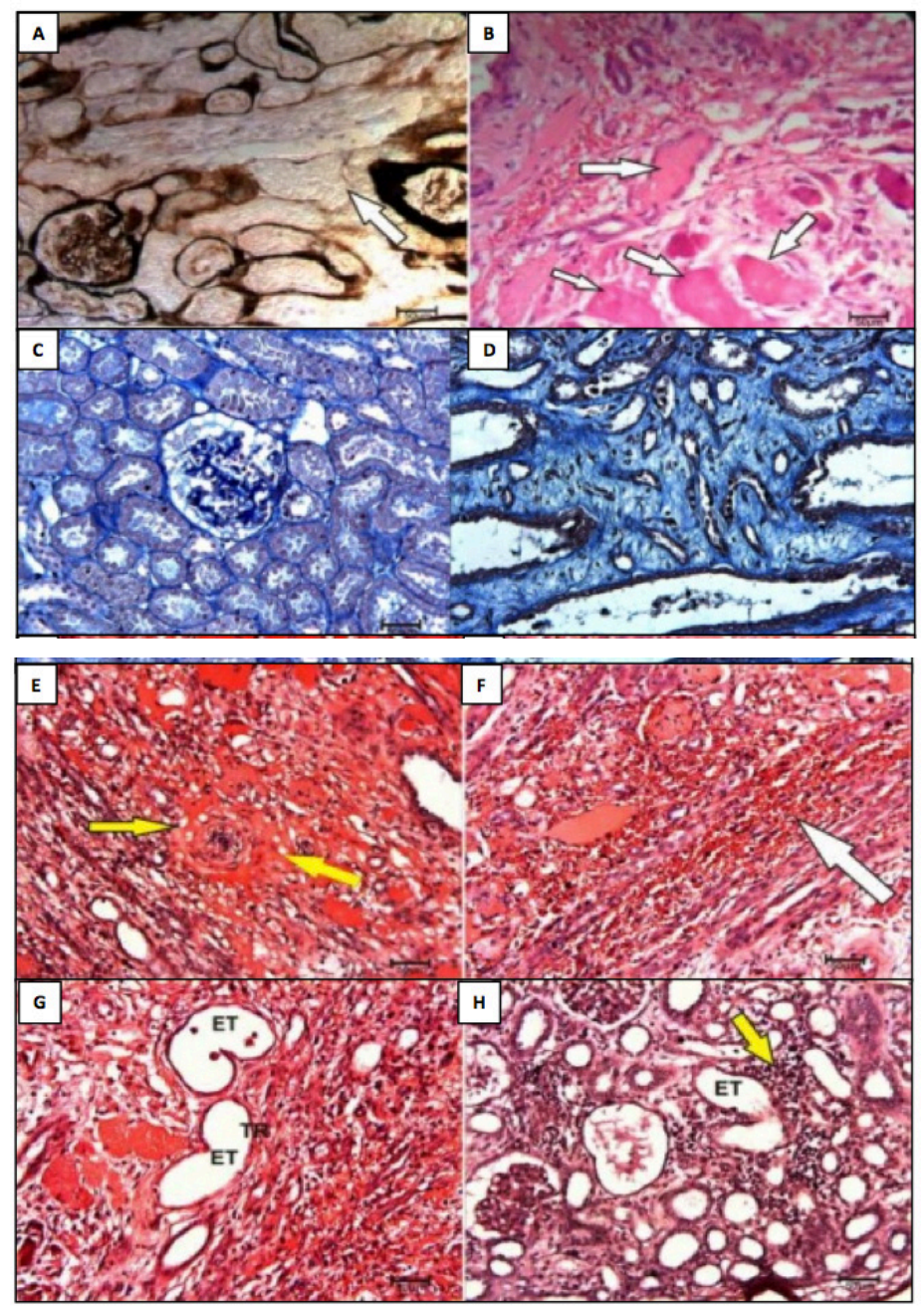

FIGURE 5 - Photomicrograph of collared peccary (Tayassu tajacu) kidney after induction of partial ischemic nephropathy. A. Broken tubular basement membranes (arrow). Coloration: PAMS Increase: x200. B. Intratubular hyaline cylinders (arrows). Coloration: HE, magnification: x200. C. Dilatation of the renal tubules. ET: tubular ectasia; TR: renal tubule. Coloration: HE, magnification: x200. D. Dilation of renal cortical tubules and mononuclear interstitial nephritis (yellow arrow). ET: tubular ectasia. Coloration: HE, magnification: x200. Normal. E. Kidney. F. Kidney after partial induction of ischemic nephropathy. Intense interstitial fibrosis stained blue. Coloration: Trichrome Massom, Magnification: x200. G. Perivascular edema (yellow arrows). HE, x200. H. Extensive focal hemorrhage (white arrow). Coloration: HE, magnification: x200. 


\section{Discussion}

The experimental studies of the induction of ischemic nephropathy technoque for partial occlusion of the renal artery were satisfactory. The animals used in this study had similar disease characteristics with lesions in the renal parenchyma, as reported by Konopka et al. ${ }^{1}$ stating that stenosis can be detected by an atraumatic ligation with surgical suture. A reduction was observed in the present experiment of about 3/4 of initial diameter of the artery to produce hemodynamically significant stenosis confirming the effectiveness of an experimental model.

Studies in the literature on the renal vascular anatomical pattern in collared peccary ${ }^{21}$ and phylogenetically related species $^{22-24}$, were important to the success of the surgery, since they supported the technique used for dissection and occlusion of the left renal artery to induce renal ischemia.

Biochemical analysis of the animals showed that for serum urea levels before and after inducing ischemic nephropathy, values were taken absolutely within the numerical range for the reference species ${ }^{18-20}$. Increasing concentrations of urea and serum creatinine are considered diagnostic factors for Acute Renal Failure (ARF) and Chronic Renal Failure (CRF) ${ }^{26}$. However, although these levels remained stable in research, it can be said that they are not good markers to indicate either acute or chronic renal lesions, because they did not alter even with this unilateral injury.

The hematological profile of the animals showed no differences between treatment groups and were in accordance with references to species ${ }^{18,28}$. Thus, the animals showed no changes in normocromia normocitosis and platelets in all phases of the experiment, including the control group. However, on the 5 th day after surgical induction a slight decrease was observed, which can be justified by restraint, therefore, both chemical and physical restraint can cause changes in haematological parameters in animals ${ }^{28,29}$. The platelet count of the animals was within the range found for domestic pigs ${ }^{30}$.

The leucocyte count showed morphologically normal leukocytes during the experiment, which may characterize an ARF or CRF even show a stress response to illness with neutrophilia ${ }^{31}$ However, as in all periods the average value found was above the benchmark for peccaries ${ }^{18,28}$, featuring leukocytosis, it is believed that these values consist of a standard among animals used and were not caused by the induction of nephropathy.

Physical examination of the urine of the animals showed predominance of light yellow color and usually clear urine indicating normality with normal urine specific gravity the same as the normal values for domestic pigs ${ }^{32}$. Urinary evaluation showed proteinuria, crystalluria and casts in all evaluation periods of the experiment, including the control group, that therefore were not caused by induced nephropathy and make the profile for the animals used.

Protein values obtained were well below the standard for the species ${ }^{18}$, however, the proteins in a healthy individual are usually not found in urine. This occurs because the proteins have a high molecular weight and the few that can pass through the glomerular filter are then reabsorbed by the renal tubules. A small amount may, however, escape and appear in urine in trace amounts, especially in concentrated urine ${ }^{33}$. However, the small proteinuria present in healthy animals can be caused by stress, as well as in commercial pig farming where it is a problem in the system, or a high amount of protein ingested ${ }^{33}$. Thus, the protein requirement of the collared peccary is $14 \%$, relatively low crude protein ${ }^{17}$ and nutritional requirement of $794.05 \mathrm{kcal} / \mathrm{day}^{34}$, however, the diet offered to the animals contained $16 \%$ crude protein in the diet of the animals, thus, it may have caused proteinuria in animals both on day 0 and in the other periods of the experiment.

Ultrasound examination showed an increase in right renal length on day 10 compared to day 5 after induction. Compared to reference values ${ }^{20}$, there was an increase from the 10 th day with a slight decrease on day 20, but still larger than the referenced values. The right kidney showed no wide divergence cited as the standard for the species $^{20}$, nor statistically significant difference, however, a slight increase was observed from the 10th day of occlusion, as occurred with renal length. The discrete contralateral hypertrophy is probably due to an early compensatory intact response to maintain the function of both kidneys, since one had decreased functional capacity, a fact that also occurred in rabbits with induced $\mathrm{CRF}^{35}$.

In Doppler ultrasound, the rate of intra -renal resistance to blood flow can be visualized and evaluated by calculating the $\mathrm{RI}^{36}$, which shows a reflection of renal parenchymal resistance ${ }^{37}$. Mean RI values calculated in each kidney may assist in the diagnosis of obstructive unilateral pathologies ${ }^{38-41}$. The resistivity index and flow velocity in the right and left kidneys showed no alterations, probably due to the ability of renal autoregulation, which allows the maintenance of constant organ blood flow despite possible changes in existing infusion, treating initial compensatory responses without any neurohormonal influence. The intrinsic renal autoregulatory mechanism maintains blood flow constant over a wide range of blood pressures (from 60 to $180 \mathrm{mmHg}$ in humans), however, above these thresholds self-regulation no longer occurs ${ }^{42}$.

In the case of RI, compared to a study made in humans post-transplant, it was found that the RI was not significantly different between patients with edematous alterations not only fibrosis with tubular atrophy and interstitial fibrosis and glomerular 
and vascular sclerosis ${ }^{43}$, a fact that explains the lack of statistical difference in the injured peccary kidney has proven areas of intense interstitial fibrosis.

However, there was a small increase in the values of the left renal RI and decreased flow velocity from the 10th day of occlusion. This slight change was possibly due to the narrowing in the artery of the distributor body that caused an increase in the resistance and consequently the reduction of perfusion pressure and flow velocity ${ }^{44}$. It is known that higher than normal values for resistance index were reported in some nephropathies ${ }^{36}$. A reverse situation occurred in the intact contralateral kidney with decreased RI and increased flow velocity, as was mentioned earlier probably due to the onset of intrinsic compensatory response.

Histopathological examination was conclusive to validate the induction of renal ischemia in peccaries. The hematological and biochemical tests were within the reference range for the species. This is due to the fact that the model used in both kidneys and stenosis could maintain normal levels of blood and urinary metabolites in the body through the healthy contralateral kidney. This fact has been observed in studies on the correlation of sonographic and histopathological findings in renal diseases ${ }^{45}$.

Major renal histopathological changes of the peccary with induced ischemia were degeneration and tubular necrosis. These injuries are directly related to ischemia, because a decrease in oxygen delivery to the kidney leads to tubular degeneration. The loss of integrity of the cytoskeleton of renal tubular cells and the disruption of actin initial events are crucial to the occurrence of nephrosis, the microvilli are lost with the cytoskeleton ${ }^{46}$. Cell adhesion is hindered in the narrow joints (occludin loss) and along the basolateral membranes (loss or redistribution of the integrin). These events facilitate the detachment of tubular cells, which are released from the tubular basement membrane and also one from the other ${ }^{46}$, confirming the histopathological changes observed in this study, in which occasionally piknotic intratubular cells were observed.

With the persistence of the ischemic stimulus, cell necrosis occurred and was observed in the tubular epithelium of the kidneys subjected to ischemia of the animals. Cell necrosis was marked by nuclear changes such as pyknosis, karyorrhexis karyolysis or associated with cytoplasmic homogeneity and acidophilia. Often battered cells still survive presenting only sublethal changes such as vacuolar or hydropic degeneration with mild metabolic changes, but still compatible with cell survival. Associated with cell death by necrosis, apoptosis regulatory genes are also activated culminating in the greatest loss of cells along the nephron segments that contribute to the onset of renal failure ${ }^{47-49}$. Another factor that contributes to the pathophysiology of acute tubular necrosis is intra-renal vasoconstriction, which may compromise the circulation by $50 \%$, which hampers oxygen release, exacerbating ischemia ${ }^{46}$.

In mice, morphological changes consistent with ischemic necrosis of renal tubular cells are found after at least 30 minutes of ischemia and after over an hour of reperfusion ${ }^{49,50}$ and in rats subjected to ischemia only renal ${ }^{1}$. Common findings relate to renal injury in the ischemic swine model ${ }^{51}$.

The changes observed in the kidneys of the animals, subjected to ischemia, were predominantly tubular glomeruli with a few morphological changes. This is due to the fact that in the glomeruli, in spite of ischemia, do not undergo necrosis because they are predominantly connective structures and therefore have lower metabolism. The tubular cells, which are epithelial, have high metabolism, especially the proximal tubule cells, which are rich in mitochondria ${ }^{31}$. The tubular atrophy present in $83.3 \%$ of the animals with induced disease was in accordance with a similar experiment on rats, in which $89.3 \%$ (75/84) of animals also showed this lesion ${ }^{1}$.

Costa et $a l{ }^{35}$ in an experiment in rabbits induced nephropathy and reported that the most striking feature of the chronicity of the lesions was characteristic subcapsular interstitial fibrosis, dilatation of renal glomeruli or collectors and dilated ducts with areas of sclerosis tubules. These observations were also identified in this research. The maintenance and chronicity of ischemia for 20 days resulted in renal interstitium, extensive fibrosis, glomeruli atrophy, partial or total glomerular sclerosis. Allied to this, there was mononuclear cell infiltration, hemorrhage and congestion, demonstrating tissue reaction in contrast to the ongoing damage caused. Similar results were found in the ischemic rat model ${ }^{1,49}$, and domestic pigs ${ }^{51}$.

Typical lesions of chronic kidney disease in dogs and cats include a variety of degrees of tubulointerstitial lymphoplasmacytic nephritis, fibrosis, tubular death, hypertrophy of some tubular epithelial cells, mineralization of tubular basement membrane and interstitium, glomerulosclerosis and obsolescent glomerulus ${ }^{31}$. However, in experiment in mice ${ }^{1}$, interstitial infiltration occurred early on from the first time (seven days) of occlusion, in almost all $98.8 \%(83 / 84)$ of the animals, a highly significant occurrence throughout the experiment.

It is known that in acute IRA caused by nephrosis interstitial inflammation is minimal, but in IRA caused by nephritis it is substantial. The absence of fibrosis and loss of nephrons give more support to the diagnosis of ARF in the initial phase than for CRF. Thus, one cannot state the degree of nephritis found in this experiment, since all histological analyzes were performed only at 
20 days. The chronicity of the lesions is marked by the recruitment and proliferation of immune cells, increased extracellular matrix, collagen proliferation and fibrosis ${ }^{51}$. Thus, the continued presence of glomerular and interstitial fibrotic lesions could determine progressive loss of nephrons and glomerular filtration ${ }^{4}$, it is likely that tubulointerstitial fibrosis and inflammation contribute to the progressive failure of nephrons ${ }^{35}$.

Induced nephropathy in collared peccary also showed thickening of the membrane of the glomerulus, glomerular and tubular capsule. Similar results were found in experiments with rats subjected to unilateral nephrectomy, but with mineralization of basement membranes of kidney tubules and Bowman capsule ${ }^{35}$. Congestion and interstitial edema were detected in kidney injury of the animals, as well as in rats induced with nephropathy ${ }^{35,49}$. Partial or total glomerular sclerosis found in $100 \%$ of our animals is a common finding in rats and rabbits, as well as proximal tubular atrophy and increased apoptosis, common in experimentally induced $\mathrm{CRF}^{1,35}$.

The presence of hyaline casts is common in various kidney diseases and were found in $66.7 \%$ of the individual injured kidneys. These correspond to plasma proteins filtered at the glomerulus and condensed in the tube, thus indicating that the glomerulus is more permeable than normal. In chronic renal failure there is an increased movement by hyperfiltrated protein in the glomerular capillaries and urinary space mesangium, a process known as "protein traffic". The increase in glomerular filtration of proteins is toxic to the kidney and can contribute to the progression of renal disease ${ }^{31}$.

Bilateral partial occlusion of the kidneys of animals would likely lead to a systemic disease, inducing them to a lethal box , incompatible with the purpose of the study that prioritizes the creation of an experimental model. Thus, one can justify the potential of the peccary as an animal model because of its rapid healing and postoperative recovery; high resistance of these animals that favors clinical and surgical procedures; it is cheap to acquire and maintain and adapts easily to captivity. The other swine models such as the mini pig, on the other hand, has a high market price and needs greater care in its management ${ }^{26}$.

\section{Conclusions}

The collared peccary is a good model for ischemic nephropathy induced by surgery. It is a very study animal, easy to adapt to captivity, and its size and body weight favor manipulation, and it has a low maintenance cost compared to other swine models. It enables the achievement of therapeutic research, including experiments using stem cells for renal tissue repair.

\section{References}

1. Konopka CL, Jurach J, Wender OCB. Experimental model for the study of chronic renal ischemia in rats: morphologic, histological and ultra-structuralanalysis. Acta Cir Bras. 2007;22(1):12-21. doi: 10.1590/S0102-86502007000100003.

2. Goldblatt H, Lynch J, Hanzal RF, Summerville WW. Studies on experimental hypertension. I. The production of persistent elevation of systolic blood pressure by means of renal ischemia. J Exp Med. 1934;59:347-79. PMID: 19870251.

3. Jacobson HR. Nephology Forum: ischemic renal disease: an overlooked clinical entity? Kidney Int. 1988;34:729-43. PMID:3059028.

4. Cheung CM, Hegarty J, Kalra PA. Dilemmas in the management of renal artery stenosis. Br Med Bull. 2005;73-74:35-55. PMID: 3059028.

5. Chade AR, Bentley MD, Zhu X, Rodriguez-PorcelM, Niemeyer S, Amores-Arriaga B, Claudio Napoli, Ritman EL, Lerman AandLerman LO. Antioxidant intervention blunts renal injury in experimental renovascular disease. J Am Soc Nephrol. 2004;15:95866. doi: 10.1097/01.ASN.0000117774.83396.E9.

6. Labidi J, Touat D, Abdelghanim K, Ajili F, Ariba YB, Abdelhafidh NB, Louzir B, Othmani S. Renovascular hypertension: a report of 21 cases. J Kidney Dis Transpl. 2014;25(1):96-100. PMID:24434389.

7. Patel J, Pancholi N, Gudehithlu KP, Sethupathi P, Hart PD, Dunea G, Singh AK. Stem cells from foreign body granulation tissue accelerate recovery from acute kidney injury. Nephrol Dial Transplant. 2012;27(5):1780-86. doi: 10.1093/ndt/gfr585.

8. Cabral RM, Ferraz MS, Rizzo MS, Sousa FCA, Rodrigues MN, Ibiapina PB, Ambrósio CE, Carvalho MAM. Kidney injury and cell therapy: preclinical study. Microsc Res Tech. 2011;75:566-70. doi: 10.1002/jemt.21092.

9. Fagundes DJ, Taha MO. Modelo animal de doença: critérios de escolha e espécies de animais de uso corrente. Acta Cir Bras. 2004;19 (1):59-65. doi: 10.1590/S0102-86502004000100010.

10. Monteiro R, Brandau R, Gomes WJ, Braile. DM, Trends in animal experimentation. Rev Bras Cir Cardiovasc. 2009;24(4):506-13. doi: 10.1590/S0102-76382009000500012.

11. Vodička P, Smetana K, Dvořánková B, Emerick T, Xu YZ, Ourednik J, Motlík J. The miniature pig as an animal model in biomedical research. Ann N Y Acad Sci. 2005;1049(1):161-71. doi: 10.1196/ annals.1334.015.

12. Gongora J, Moran C. Nuclear and mitochondrial evolutionary analyses of Collared, White-lipped, and Chacoan peccaries (Tayassuidae). Mol Phylogenet Evol. 2005;34:181-9. doi:10.1016/j. ympev.2004.08.021.

13. Minervino AHH, Araújo CASC, Barrêto-Júnior RA, Soares HS, Oliveira MF, Mori CS, Neves KAL, Vale WG, Gennari SM, Ortolani EL. Serum biochemistry of collared peccaries (Pecari tajacu) in captivity in Northeastern Brazil. Pak Vet J. 2014. In press.

14. Hellgreen EC, Lochmiller RL, Amoss MS, Grant-Jr WE. Endocrine and metabolic responses of the collared peccary (T. tajacu) to immobilization with ketamine hydrochloride. J Wildl Dis. 1985;21:417-25. PMID:3001372.

15. Costa DS, Paula TAR. Coleta e avaliação do sêmen de catetos (Tayassu tajacu). Biota Neotrop. [online] 2005;5(2):131-6. doi:10.1590/S1676-06032005000300009.

16. Dorandeu F, Baille V, Mikler J, Testylier G, Lallement G, Sawyer T, Carpentier P. Protective effects of S (+) ketamine and atropine against lethality and brain damage during soman-induced status epilepticus in guinea-pigs. Toxicology. 2007;234:185-93. doi: 10.1016/j.tox.2007.02.012.

17. Barreto GR, Hernandez OE, Ojasti J. Diet of peccaries (Tayassu 
tajacu and Tayassu pecari) in dry forest of Venezuela. J Zool. 1997;241:279-84. doi: 10.1111/j.1469-7998.1997.tb01958.x.

18. Lochmiller RL, Grant WE. Serum chemistry of collared peccary (Tayassu tajacu). J Wildl Dis. 1984;20(2):134-40. doi: 10.7589/00903558-20.2.134.

19. Schettini, Z, Li E., Gálvez C, Montoya G, Sánchez P. Perfil bioquímico sanguíneo hepático y renal en el sajino (Tayassu tajacu) criado en cautiverio en la amazonía peruana. Rev Investig Vet Perú. 2005;16(2):175-9.

20. Peixoto GCX, Oliveira IRS, Alves ND, Oliveira MF, Silva AR. Abdominal exploration in captive collared peccaries (Tayassu tajacu) by ultrasonography. Anat Histol Embryol. 2012;41:256-61. doi: $10.1111 /$ j.1439-0264.2011.01129.x.

21. Machado GV, Cavalcante Filho MF, Miglino MA, Carvalho MAM, Santos TC, Lesnau GG. Comportamento anatômico das artérias renais em catetos (Tayassu tajacu Linnaeus, 1758). Vet Not. 2000;6(1):17-25.

22. Romagnolli P, Machado GV, Miglino MA. Segmentos arteriais dos rins de queixadas (Tayassu pecari, Linnaeus, 1795). Braz J Vet Res Anim Sci. 2003;40:205-12. doi: 10.1590/S141395962003000900008

23. Carvalho MAM, Miglino MA, Machado GV, Júnior AANM, Vale EF, Azevedo LM. Segmentação anatomo-cirúrgica arterial do rim de javali (Sus scrofa) adulto. Rev Biotemas. 2006;19(4):85-90.

24. Romagnolli P, Reolon J, Gomes JO, Motter SA, Masseto A, Rodrigues FB, Furlan MM. Caracterização vascular dos setores e segmentos arteriais renais de suínos. Arq Ciênc Vet Zool. 2010;13(2):93-7.

25. Bellomo R, Ronco C, Kellum JA, Mehta RL, Palevsky P. Acute renal failure - definition, outcome measures, animal models, fluid therapy and information technology needs: the Second International Consensus Conference of the Acute Dialysis Quality Initiative (ADQI) Group. Crit Care. 2004;8(4):R204-12. doi: 10.1186/cc2872.

26. Giraud S, Favreau S, Chatauret N, Thuillier R, Maiga S, Hauet T. Contribution of large pig for renal ischemia-reperfusion and transplantation studies: the preclinical model. J Biomed Biotechnol. 2011;2011:532127. doi: 10.1155/2011/532127.

27. Peixoto EF; Lamounier TAC. Métodos laboratoriais para a identificação da insuficiência renal crônica. Acta Ciênc Saúde. 2012;2(1):39-52.

28. Almeida AMB, Nogueira-Filho SL, Nogueira SS, Munhoz AD Aspectos hematológicos de catetos (Tayassu tajacu) mantidos em cativeiro. Pesq Vet Bras. 2011;31(2):173-7. doi: 10.1590/S0100736X2011000200014.

29. Batista JS, Bezerra FSB, Agra EGD, Calado EB, Godói RM, Rodrigues CMF, Soto-Blanco B. Efeitos da contenção física e química sobre os parâmetros indicadores de estresse em catetos (Tayassu tajacu). Acta Vet Brasilica. 2009;3(2):92-7.

30. Almeida RF, Lopes EL, Cunha Nunes R, Matos MPC, Fioravanti MCS, Sobestiansky J, Rufino LM. Ferro e imunidade humoral em suínos alimentados com fitase e níveis reduzidos de fósforo. Ciênc Anim Bras. 2007;8(4):767-76. doi: 10.5216/cab.v8i4.432.

31. DiBartola SP,Buffington CA, Chew DJ, McLoughlin MA, Sparks RA. Development of chronic renal disease in cats fed a commercial diet. J Am Vet Med Assoc. 1993;202(5):744-51. PMID: 8454506.

32. Almond GW, Steves JB. Urinalysis techniques for swine practitioners. Compend Contin Educ. 1995;17:121-9.

33. Pôrto RNG, Sobestyansky J, Matos MPC, Gambarine ML. Aspectos físicos, químicos e microbiológicos da urina de matrizes suínas descartadas. Cienc Rural. 2003;33(2):7-8.

34. Zervanos SM, Hadley NF. Adaptational biology and energy relationships of the collared peccary (Tayassu tajacu). Ecology. 1973;54(4):759-74. doi: 10.2307/193567.
35. Chagar VLA. Modelo cirúrgico de insuficiência renal crônica. Estudo em coelhos. Rev Col Bras Cir. 2009;36(1):78-84. doi: 10.1590/S0100-69912009000100014.

36. Tublin ME, Bude RO, Platt JF. The resitive index in renal Doppler sonography: where do we stand?. Am J Roentgenol. 2003;180(4):885-92. PMID:12646425.

37. Rivers BJ, Walter PA, Polzin DJ, King VL. Duplex doppler estimation of intrarenal pourcelot resistive index in dogs and cats with renal disease. J Vet Intern Med. 1997;11(4):250-60. doi: 10.1111/j.1939-1676.1997.tb00099.x.

38. Novellas R, Ruiz de Gopegui R, Espada Y. Assessment of renal vascular resistance and blood pressure in dogs and cats with renal disease. Vet Rec. 2010;166(20):618-23. PMID: 20472873.

39. Gálvez SF, Delgado MMI, Rioja SLA, Blas MM, Durán FM, Usón GJ. Utilidad del índice de resistencia renal en la valoración y evolución de la uropatía obstructiva. Estudio experimental. Acta Urol Esp. 2007;31(1):38-44. PMID: 17410985.

40. Platt JF, Rubin JM, Ellis JH. Acute renal obstruction: evaluation with intrarenal dúplex Doppler and conventional US. Radiology. 1993;186:685-8. PMID: 8430174.

41. Platt JF, Rubin JM, Ellis JH. Distinction between obstructive and non obstructive pyelocaliectasis duplex Doppler sonography. Am J Roentgenol. 1989;153(5):997-1000. doi: 10.2214/ajr.153.5.997.

42. Rivers BJ, Walter PA, O'Brien TD, Polzin DJ. Duplex Doppler estimation of pourcelot resistive index in arcuate arteries of sedated normal cats. J Vet Intern Med. 1996;10(1):28-33.

43. Gao J, Rubin JM, Xiang DY, He W, Auh YH, Wang J, Min R. Doppler parameters in renal transplant dysfunction, correlations with histopathologic changes. J Ultrasound Med. 2011;30(2):16975. PMID:21266554.

44. Tublin ME, Tessler FN e Murphy MN. Correlation between renal vascular resistance, pulse pressure, and the resistive indexin isolated perfused rabbit kidneys. Radiology. 1999;213:258-64. doi: 10.1148/ radiology.213.1.r99oc19258.

45. Carvalho APM, Salavessa CM, Silveira LS. Ultrassonografia e histopatologia renal em cães. Arq Bras Med Vet Zootec. 2010;62(4):1015-7. doi: 10.1590/S0102-09352010000400038.

46. Costa JAC, Vieira Neto OM, Moysés Neto M. Insuficiência renal aguda. Medicina (Ribeirão Preto Online). 2003;36:307-24. doi:10.11606/issn.2176-7262.v36i2/4p307-324.

47. Gobe G, Zhang XJ, Cuttle L, Pat B, Willgoss D, Hancock J, Endre Z. Bcl-2 genes and growth factors in the pathology of ischaemic acute renal failure. Immunol Cell Biol. 1999;77(3):279-86. doi:10.1046/j.1440-1711.

48. Cuttle L, Zhang XJ, Endre ZH, Winterford C, Gobé GC. Bcl$\mathrm{X}(\mathrm{L})$ translocation in renal tubular epitheial cells in vitro protects distal cells from oxidative stress. Kidney Int. 2001;59(5):1779-88. doi:10.1046/j.1523-1755.

49. Feitosa EAN, Taha MO, Fagundes DJ, Takiya CM, Cardoso LR, Campos DM. Estudo da morfologia renal após a oclusão da aorta abdominal infra-renal em ratos. Rev Col Bras Cir. 2005;32(4):17882. doi: 10.1590/S0100-69912005000400004

50. Kelly KJ, Plotkin Z, Vulgamott SL, Dagher PC. P53 mediates the apoptotic response to GTP depletion after renal ischemia reperfusion: protective role of a p53 inhibitor. J Am Soc Nephrol. 2003;14(1):128-38. doi: 10.1097/01.ASN.0000040596.23073.01.

51. Jayle C, Favreau F, Zhang K, Doucet C, Goujon JM, Hebrard W, Hauet $\mathrm{T}$. Comparison of protective effects of trimetazidine against experimental warm ischemia of different durations: early and longtermeffects in a pig kidney model. Am J Physiol. 2007;292(3):108293. doi: 10.1152/ajprenal.00338.2006. 
Bezerra DO et al.

\section{Acknowledgement}

The Federal University of Piaui for their support and encouragement during the completion of the master program.

\section{Correspondence:}

Maria Acelina Martins de Carvalho

Universidade Federal do Piauí

Campus Ministro Petrônio Portela

64049-550 Teresina - PI Brasil

Tel.: (55 86)3215-5741

mcelina@ufpi.edu.br

Received: Apr 18, 2014

Review: Jun 18, 2014

Accepted: July 22, 2014

Conflict of interest: none

Financial sources: Coordination of Improvement for Higher Academic Staff (CAPES) and National Council for Scientific and Technological Development (CNPq)

${ }^{1}$ Research performed at Preclinical Studies Center (CEPREC), Integrated Nucleus of Morphology and Stem Cell Research (NUPCelt), Department of Veterinary Morphophysiology, Federal University of Piaui (UFPI), Teresina-PI, Brazil. Part of Master degree thesis, Postgraduate Program in Animal Science, UFPI. Tutor: Maria Acelina Martins de Carvalho. 